\title{
THE JOURNAL IN RETROSPECT
}

\section{BY RUDOLF KIRK}

Professor KIRK, now Chairman of the Department of English, Rutgers, will retire on July 1,1963 , after thirty-five years at the University.

7 HE Journal of the Rutgers University Library was actually born at the formal organization meeting of the Associated Friends of the Library of Rutgers University, held on $2 \mathrm{I}$ May 1937, but its conception dated back some four or five years before that time. As the Librarian, Dr. George A. Osborn, and others considered the holdings of the Library, its important and completely buried manuscripts and valuable rare books, its significant special collections, they dreamed of some sort of publication that would make available to scholars these treasures and at the same time inspire students to delve further into the resources of the Library. They hoped, of course, that when the owners of precious books and papers learned that the Library was bringing its holdings to light, these people might be glad to give their possessions to the Library and, thus, further to increase its holdings. Indeed, if these hidden rarities could be made available, the Rutgers University Library would grow in scholarly reputation, and its friends would multiply. And so, gradually, the idea of a periodical took form.

It will be well to name over some of the men and women who were instrumental in forming the Associated Friends and in so doing remind ourselves of those who fostered the Library a generation ago and whose devoted services brought into existence the Journal. Perhaps the place to begin will be to recall that on 5 March 1937 an informal meeting of Trustees and faculty members was held in the Trustees' Room of Old Queens. After a formal-informal discussion led by Mr. Richard T. Greene, the chairman of the Trustees' Committee of the Library, Dr. Jacob G. Lipman was asked to act as chairman and to prepare for the organization meeting that was planned for the 2 I st of May. Then on 2 I May the Friends convened to adopt a constitution and to have dinner together in the now almost forgotten Alumni House on Queens Campus. The purposes of the Associated Friends, as set down in the Constitution were "to main- 
tain an organization of persons interested in books; to assist in bringing to the Library of Rutgers University funds for special needs beyond the command of the Library budget; to encourage gifts of books and manuscripts; and to cooperate with the Librarian and the Library Advisory Board in the development of the resources of the Library under the direction of the Library Committee of the Board of Trustees of Rutgers University." Dr. John W. Mettler, of the Class of I 899, was elected President, Dr. Gabriel Wells, the wellknown New York book dealer, Honorary President. Six devoted friends of the Library were named Vice-presidents-Dr. Ralph G. Wright, Mr. Duncan D. Sutphen, Dr. William H. S. Demarest, Mrs. Edward L. Katzenbach, Mr. Richard T. Greene, and Mr. Drury W. Cooper. The future Librarian, Dr. Donald F. Cameron, was elected Secretary and Mr. Nelson Dunham, Treasurer. To these names we may add those of other members of the Executive Committee: Mr. Clifford P. Case, Mr. J. Harold Johnston, Miss Alice G. Higgins, Dr. Carl R. Woodward, Dr. Jacob G. Lipman, and Dr. Ernest E. McMahon.

At this meeting plans for publishing the Journal were confirmed, and the present writer was appointed as its Editor. Others named to the Editorial Board were Dr. Osborn, Dr. Oral S. Coad, Dr. L. Ethan Ellis, Dr. Max Gideonse, Mr. Alan E. James, Mr. Earl S. Miers, and Dr. Carl R. Woodward.

From this time until the first number was published a few days before Christmas, the Editor was in a state of excitement and uneasiness. He secured "Greetings from the President," for Dr. Clothier was heart and soul behind this effort. Then the venerable Dr. Demarest was asked to write a "History of the Library"-he seemed to have witnessed all Rutgers history since I766! Dr. George A. Osborn wrote on "The Use of the Library." Dr. Robert T. Thompson went into the Neilson Papers in the Library and gave us a delightful account of "Colonel Neilson: Salt Merchant," and Dr. C. E. Partch wrote on "Century-Old Textbooks in the Rutgers Library."

Any editor's troubles ought to have ended with such a group of articles for his first issue, but they did not end for this editor. What should be the color of the cover of the new Journal? A dingy grey? An easily soiled tan? White? Blue? Or red? The editor consulted 
person after person. Some strongly objected to red. A few agreed that it might do, but they were indifferent. In a turmoil of indecision the Editor took samples of colored paper to one of his classes of Juniors and Seniors and put the matter squarely up to the boys. They considered for two or three minutes and then came out unanimously in favor of a good Rutgers scarlet. Their decision was the correct one and has prevailed for a quarter of a century.

As this brief history draws to a close, the writer wishes to express his deep appreciation to all those-living and dead-who forwarded the enterprise of establishing and continuing the Journal. Among the living he is especially grateful to his two successors as Editor, Dr. Leslie A. Marchand and Dr. Arthur C. Young, and to the present Librarian, Dr. Donald F. Cameron. Among those who are no longer with us, the most notable figure in the history of the Journal was Dr. George A. Osborn. 